\title{
SPACE TOURISM - BETWEEN COMPETITION AND COOPERATION OF STATES AND NON-STATE ENTITIES
}

\author{
Agnieszka BÓGDAL-BRZEZIŃSKA* \\ University of Warsaw, Faculty of Political Science and International Studies, Poland, e-mail: bogdal@uw.edu.pl
}

\author{
Jan A. WENDT
}

University of Gdańsk, Faculty of Social Sciences, Institute of Socio-Economic

Geography and Spatial Management, Poland, e-mail: jan.wendt@ug.edu.pl

\begin{abstract}
Citation: Bógdał-Brzezińska, A., \& Wendt, J.A. (2021). SPACE TOURISM - BETWEEN COMPETITION AND COOPERATION OF STATES AND NON-STATE ENTITIES. GeoJournal of Tourism and Geosites, 38(4), $1151-1156$. https://doi.org/10.30892/gtg.38421-755
\end{abstract}

\begin{abstract}
The aim of the research is an attempt to answer the question about the inevitability of cooperation between states and commercial entities as part of private-public partnership in the development of astrotourism and the challenges related to it. In the undertaken research and development of materials, the classical method of analysis of existing data information (desk research) was used. In order to indicate similarities and differences, and to achieve the objectives of the research and to verify the hypothesis, a SWOT analysis was performed. A number of safety issues in astrotourism are still unregulated. Among modern countries preferring to maintain a monopoly in space, authoritarian countries dominate, such as Russia, where every sector of space exploration, including space tourism, depends on the state. In democratic countries, private entities are largely the partners or service providers of the states. In the near future, private entities will set the direction of space tourism development. States will abandon their monopoly on regulatory and organizational powers in space exploration. However, for reasons of their own security and safety interests, they will leave themselves in control of this sector. The latter will lead to the development of public-private partnerships.
\end{abstract}

Key words: astrotourism, private entities, security, space exploration, space tourism, state, tourism

$* \quad * \quad * \quad * \quad * \quad *$

\section{INTRODUCTION}

With its political roots, space tourism dates back to the arms race undertaken by superpowers, primarily the USSR and the USA, with the use of military innovations in the period of the so-called cold war. The US-Soviet rivalry in space inspired smaller countries to participate in international activity for the legal regulation of the status of space and to consider space policy as a condition for the development of their economies. Since the turn of the 20th and 21 st centuries, commercial space flights have become the subject of scientific interest, and the journal "Acta Astronautica" has become an important forum for scientific debate (Zhang and Wang, 2020; Pásková et al., 2021). The initially eclectic discourse has become more orderly, competing definition categories have emerged, such as astronomical tourism, which includes the observation of astronomical phenomena in particularly favorable destinations, or the classic exploring of space stations (Koshim et al., 2019) or space-related artifacts. However, a new impetus for astrotourism was given by cosmic commercial travel and space tourism (Webber, 2013). There are terms treating space tourism as being (traveling or living) in outer space for recreational purposes. The criteria are the distance from the Earth's surface in connection with the achieved state of weightlessness (Różycki and Kruczek, 2017). For the purposes of this study, a simple classification of astrotourism into terrestial, high atmosphere and space tourism was adopted. The latter, to which this research is devoted, can be divided into suborbit, on Earth orbit, beyond orbit and interstellar tourism (Cater, 2010; Fayos-Solá et al., 2014; Pásková et al., 2021).

The phenomenon of space tourism is considered in relation to the problem of tourism space, and the subject of research is the relationship between real space and outer space (Łoboda, 2017; Bógdał-Brzezińska, 2020a). In this space, there are special conditions for human existence, so a special regime of requirements for travelers / tourists in space is formed. It was assumed that among the entire population there is a group of people meeting the health and financial criteria. This leads to the conclusion that the issue of transport accessibility or, more broadly, communication accessibility for the development of space tourism becomes the key issue. As already mentioned, the beginnings of space flights are associated with the military rivalry of great powers. However, we are currently witnessing several successful commercial flights (Cole, 2015; Chang, 2015; Chang and Chern, 2016). With this in mind, the aim of the research undertaken is to try to answer the question about the inevitability of cooperation between states and commercial entities as part of private-public partnership in the development of astrotourism, including space tourism and related challenges (Spector et al., 2017). We hypothesize that in the near future private (commercial) entities will set the direction for the development of astrotourism and space tourism. States, in turn, will relinquish their monopoly on regulatory and organizational powers in the field of space exploration. However, they will leave themselves in control of the space security sector.

\footnotetext{
* Corresponding author
} 


\section{MATERIALS AND METHODS}

In the undertaken research and development of materials, the classic method of analysis of existing data (desk reasearch) was used, which is the result of three groups of methods, namely content analysis, statistical data analysis, and comparative literature analysis (Wendt and Bógdał-Brzezińska, 2018; Benghadbane and Khreis, 2019). At the beginning, literature studies were conducted in the field of the theoretical approach to space tourism (Cohen, 2017; Pásková et al., 2021), and then space tourism (Toivonen, 2020). The literature on the subject was also used, presenting political, military, economic and health determinants of tourism development (Peeters, 2018). The literature dealt with the state as the first and main deciding factor in space exploration until the end of the 20th century. It also referred to private entities whose activity determines the current development of astrotourism (Buchan, 2016). At the first stage of the research, an analysis of the health determinants in terms of the requirements for the physical condition of potential space tourists was undertaken. Then, in accordance with the classic definition of tourism, the key in its case of tourism accessibility was analyzed, i.e. the real possibilities of space exploration by the state and private entities. A comparative analysis (Bütün and Önçel, 2019) was used to compare the possibilities of the state and private entities in terms of the conditions and possibilities of implementing space tourism. In order to indicate the similarities and differences and to achieve the objectives of the research and verify the hypothesis, a SWOT analysis was performed (Helms and Nixon, 2010; Benzaghta et al., 2021), indicating the strengths and weaknesses of organizing trips in the field of space tourism as well as opportunities and threats to its development with from the point of view of their implementation by the state or private entities.

\section{RESULTS AND DISCUSSION}

Already at the beginning of the 21 st century, the importance of biological and health challenges in space tourism was pointed out. The minimum condition / health conditions that must be met by the service of tourist places of stay (space hotels) are discussed and determined due to the long-term stay in space and the health condition of potential guests tourists in such stations as space hotels (Smith, 2000). The latter is related to the issue of the consumer attractiveness of spaceflight. Due to the correlation between space tourism and increasing the level of well-being of a tourist as a consumer of tourist services, attention is paid to innovation as an attribute of following the latest trends. The research examines, for example, four types of consumer innovation - social, functional, hedonistic and cognitive (Chang, 2017). It points to the perception of space travel as a source of new knowledge, but above all as an experience of new forms of spending time. At the moment, they are difficult to access and limited, and confirm the high social status: the relatively good health condition of a space tourist is related to travel costs. Attention is paid to various forms of activity during a tourist space travel, e.g. special forms of practicing sports thanks to the weightlessness of the human body (Lenartowicz and Mosz, 2019).

So far, there are no global or national legal regulations regarding the health condition of people interested in participating in tourist space travel. At the current stage, neither the US government nor the key agencies, such as NASA and the Federal Aviation Administration (FAA) (King, 2020), have separate safety standards for participants in space travel. This is especially true in relation to their health condition, which is a challenge for the insurance of the risks associated with participation in commercial space flights (imbalance, cardiovascular disorders, weakening of the skeletal system). However, it should be borne in mind that in private journeys to orbit, the issue of health will play a decreasing role. This will be due to the development of the technology of securing weightless travelers and the increase in the safety level of orbital flights. Only an increase in the level of security can guarantee the development of astrotourism towards mass recreation. And only the mass phenomenon can bring financial income allowing for the development of private astrotourism and generating profit for private entities. However, so far we are still dealing with the lack of regulation of a number of issues in the field of security in space tourism. Critical studies point to the "hidden assumptions" of the space tourism industry and the lack of legal protection for passengers or the lack of protection related to risk insurance participation in space travel compared to other forms of tourism activity (Johnson and Martin, 2016).

Supporters of the thesis on the democratization of space emphasize the relatively low interest of states in its economic exploration, and especially in space tourism. This interpretation reveals the belief that the market of demand for space services will shape the main directions of further space policy of countries (The Pros ..., 2017). "While most of the large commercial missions are still closely tied to governments, many of tomorrow's smaller and cheaper missions will be funded by international teams and private interests" (Baiocchi and Welser IV, 2015). Studies by Western researchers bring a diagnosis that "the space sector is facing a multitude of new investors, who are especially engaged in the preparation of space launchers, spaceflight, space tourism, space services and equipment, surface exploration of the Moon and Mars, and asteroid mining. These emerging companies, following a 60-year paradigm of domination by state-owned space agencies, could leave their mark on the development of space technology by seeking cheaper, faster and easier access to space" (Gomes at al., 2013). In fact, with the Cold War, the absolute control of governments over space policy ended and the time when national interests drove the development of the space environment (Welser IV, 2016). After the end of the Cold War, the space sector experienced a setback as political competition in space was extinguished. Therefore, at the beginning of the 21 st century, in view of the increase in the number of companies interested in the economic use of space, the benefits and burdens resulting from the dominant role of the state in the space sector were assessed (Table 1).

Among modern countries preferring to keep a monopoly in space, authoritarian countries dominate for the above reasons, e.g. Russia, where every division of the space sector, including space tourism, is subject to state patronage. Paradoxically, in democratic countries (cf. the USA) threats appearing from the change of political power teams, which result in short (electoral) cycles of domination or marginalization of the role of the cosmos in state politics. Nowadays, space is becoming an area with which both states and non-state actors associate plans for colonization, resource 
exploitation and the creation of bases. Currently, the first successful space travel is changing this approach. Even at the beginning of the 21 st century, the threefold activity of international entities in space was indicated. In addition to the main state-centric narrative in the spirit of classical realism, the following approaches were also mentioned: liberaltransnational and constructivist with elements of critical theory. It is hard to deny that astrorealism, which was focused on the security policy and space superpower (Bógdat-Brzezińska, 2020b), dominated considerations in the field of strategic studies (Dolman, 2005; Colby, 2016). And space security researchers emphasized the threats to countries caused by the convergence of areas considered today as battlefields, where space and cyberspace were added alongside the classic earth, air and sea (Gabriel and Koven, 2018). Astrorealism treats non-state entities as a threat to national interests in space, while the liberal-transnational perspective takes into account the constructive role of commercial entities and international organizations in the development of scientific research, using the economic values of space (Weinzierl, 2018) and space tourism (Cater, 2010; Soleimani et al., 2019; Pásková et al., 2021).

Table 1. SWOT analysis from the perspective of the dominant role of states in space exploration (Source: own elaboration)

\begin{tabular}{|c|c|}
\hline Strengths & Weakness \\
\hline $\begin{array}{l}\text { - The monopoly of controlling the development of space } \\
\text { technologies in the field of national security; } \\
\text { - A guarantee of high competence of specialists with many years of } \\
\text { experience in working in governmental institutions of the space sector; } \\
\text { - Existing logistic facilities protected by the state's civil and } \\
\text { military services. }\end{array}$ & $\begin{array}{l}\text { - Slowing down of technical progress in the field of } \\
\text { implementation of space technologies under the influence of } \\
\text { political pressure; } \\
\text { - The need to allocate funds from the state budget to stimulate the } \\
\text { development of the space sector. }\end{array}$ \\
\hline Opportunities & \\
\hline $\begin{array}{l}\text { - The policy of maintaining the monopoly of control of the } \\
\text { space sector as a manifestation of modernity of the state and its } \\
\text { ability to flexibly use innovative sectors of the economy to } \\
\text { strengthen its international position. }\end{array}$ & $\begin{array}{l}\text { - Instability of the development of the space sector secondary to } \\
\text { the ideology of the ruling groups; } \\
\text { - Uncertainty of the continuation of projects financed from the state } \\
\text { budget in the conditions of financial crises or health threats (COVID 19). }\end{array}$ \\
\hline
\end{tabular}

Czajkowski (2015) indicates two types of non-state entities active in space research and having an impact on space policy: private (commercial) entities and research centers. However, it is not the classification but the legitimation of their actions that has been the axis of the scientific and political debate in recent years. Researchers emphasize the importance of the regulatory sphere, especially international space law, in defining the status and potential of non-state actors in space (Bryła, 2014; USCSP, 2016). It is related to the incompatibility of the fundamental treaties constituting the framework of the cosmic law, dated to the incubation period of human activity in space (1960s-1970s), which are incompatible with the reality of modern times. There is a contradiction between the sovereign right of states to control the airspace and the universal right to use space, which is its physical continuum (Bryła, 2014: 16). Legal disputes and the globally uncontrolled practice of placing satellites anarchy this space, meeting forecasts from the beginning of the space age (Anarchy, 1958). This leads to the creation of new concepts explaining the constructive role of non-state actors in building a new anarchy modeled on the introduction of digital innovations in cyberspace (open source anarchy) (Fidler, 2008). "Open source anarchy is a phenomenon made possible by the structural transformation made at the end of the Cold War and the simultaneous convergence of technologies that increased the material capacity of non-state actors to engage in world affairs" (Fidler, 2008: 282). The activity of commercial entities that want to implement specific, material goals of space activity develops on the basis of the commonly shared ideas of space exploration as a heritage of humanity and a specific lack of regulation that would entail restriction of access to resources.

In the face of the surge in interest of private investors in the development of the space sector, especially tourism, it is worth assessing the probability and legitimacy of the trend (Table 2), present especially in democracies, towards the complete liberalization of space services and the marginalization of the role of the state.

Table 2. SWOT analysis of space exploration by private entities (Source: own elaboration)

\begin{tabular}{|l|l|}
\hline \multicolumn{1}{|c|}{ Strengths } & \multicolumn{1}{c|}{ Weakness } \\
\hline $\begin{array}{l}\text { - Independence from trends in the electoral situation; } \\
\text { - Autonomy and flexibility of business models in the } \\
\text { conditions of an unregulated service market; }\end{array}$ & $\begin{array}{l}\text { - Dependence on the legal systems of the home countries, susceptibility to } \\
\text { - Recognition of the main businessmen interested in the } \\
\text { development of the space sector, including space tourism; } \\
\text { restrictions on economic activity by political authorities of the countries; } \\
\text { increases public interest and support for the development } \\
\text { of the new space economy. }\end{array}$ \\
\hline \multicolumn{1}{|c|}{ Opportunities } & $\begin{array}{l}\bullet \text { The heterogeneity of the space sector and its heterogeneous economic } \\
\text { situation (stagnation in the space industry after the Cold War). }\end{array}$ \\
\hline $\begin{array}{l}\text { - Actions to transform space tourism from a niche field } \\
\text { into a widely available field; } \\
\text { - Development of private enterprise focused on space } \\
\text { tourism business support. }\end{array}$ & $\begin{array}{l}\text { Threats } \\
\text { for permissibility of activities and regulatory standards suppressing } \\
\text { unlimited competition from private entities in the space industry; } \\
\text { Dependence on the political environment creating the regulatory framework; } \\
\text { The pressure to increase the availability of space tourism services may } \\
\text { result in a radical lowering of security requirements for space travel. }\end{array}$ \\
\hline
\end{tabular}

Complete liberalization of space sector services, high media pressure to reduce costs and increase the availability of space tourism travel may contribute to an increase in threats to the security of the Earth. Private (commercial) entities, in the conditions of full liberalization of the standards of space services, may reduce their costs, increasing the risk of space vehicle 
disasters resulting from technical and human errors. The competition of commercial entities in space increases the level of national security sensitivity of highly developed countries, especially in the field of satellite technologies.

In space, non-state actors are largely partners or service providers of states. During the Cold War, their role was expressed in treating the cosmos as a heritage of humanity intended for peaceful research exploration. Nevertheless, already at the end of the 1950s, there was a high awareness of the potential uses of space. Some of the applications considered are short- and longdistance transport with vehicles using traditional or new forms of propulsion; new methods in telecommunications; meteorological observations and research that, inter alia, could enable artificial climate control; exploration and exploration of space beyond the Earth's atmosphere; construction of space stations; and research and exploration of celestial bodies. Currently, space law studies mention "five main areas of possible commercial use of space by the private sector: use through the provision of space services to terrestrial clients (private or government) through the use of satellite technology and telecommunications (Bógdał-Brzezińska, 2020c); extraction of potentially depleted natural resources, such as minerals in asteroids or other planets; exploitation of renewable resources such as solar energy; commercialization of space experiences for the purposes of space tourism or scientific training; manufacturing, servicing, research and development of space products and applications" (Oduntan, 2016). For a quarter of a century, there has been a noticeable interest in the development of state space sectors by medium and small countries. Among them are also countries that are tycoons in the traditional tourism industry (Israel), and others are undergoing rapid economic growth stimulated by the mining sector (United Arab Emirates) or digital technologies (India). These countries can achieve the greatest potential benefits by initiating public-private partnerships (Table 3 ).

Table 3. SWOT analysis of space exploration by entities operating under public-private partnerships (Source: own elaboration)

\begin{tabular}{|c|c|}
\hline Strengths & Weakness \\
\hline $\begin{array}{l}\text { - Ensuring a consistent regulatory environment that excludes conflicts of } \\
\text { interest between government structures responsible for the space sector and the } \\
\text { business community; } \\
\text { - Possibility of early control of business plans by a government partner; } \\
\text { - Possibility for a commercial partner to negotiate legislative solutions } \\
\text { supporting innovations; } \\
\text { - A way to finance public investments; } \\
\text { - Increase in the rank of commercial partners towards government institutions } \\
\text { - Government guarantees for raising; } \\
\text { - Investment capital in the banking sector. }\end{array}$ & $\begin{array}{l}\text { - Potential marginalization of state institutions } \\
\text { involved in the development of the space sector, } \\
\text { which were recognizable and enjoyed the trust of } \\
\text { foreign partners; } \\
\text { - Lengthening of the decision-making process for } \\
\text { new space initiatives due to a consultation mechanism } \\
\text { between; government and commercial partners } \\
\text { - The divergence of the hierarchy of goals of both } \\
\text { partners, i.e. the primacy of the government's political } \\
\text { goals and profit optimization of commercial partners. }\end{array}$ \\
\hline Opportunities & Threats \\
\hline $\begin{array}{l}\text { - Investment risk minimization on the government side; } \\
\text { - Lowering investment costs from the state budget; } \\
\text { - International legitimacy of technological and legal solutions in the space } \\
\text { sector adopted in a given country; } \\
\text { - Transfer of business risk from a government partner to a commercial partner; } \\
\text { - Increasing the efficiency of new projects and using the experience of commercial } \\
\text { entities in the field of adapting new solutions to the technology life cycle; } \\
\text { - Lowering investment costs by providing the government space infrastructure } \\
\text { for the needs of testing technological solutions by a commercial partner; } \\
\text { - Greater guarantee of intellectual property protection in relation to space technologies. }\end{array}$ & $\begin{array}{l}\text { - No guarantees for project implementation due to } \\
\text { strong pressure from the electoral cycle; } \\
\text { - Insufficient care for the integrity of the project } \\
\text { in cases where public-private partnership is a } \\
\text { pioneering phenomenon in a given country. }\end{array}$ \\
\hline
\end{tabular}

The potential dissemination of private-public partnership in the space sector may bring a breakthrough in regulations increasing the level of space safety, including standards relating to space tourism. An additional benefit seems to be the cooperation between governments and foreign companies, which may be the foundation of new international regulations influencing the development of space law in connection with human rights, commercial law and insurance law.

The discourse on the need for private-public partnership (Borowiec, 2017) as the optimal method for the development of scientific research and commercial activities appeared both in countries with a long tradition of space flights, e.g. the USA (Jones, 2018), and in countries that have recently developed the space sector, e.g. India (ASG, 2020). However, attention is drawn to the lack of treaty regulations regarding the privatization of space, and on the other hand, to such an advanced development of technological preparation of business that it becomes possible to expand the dimensions of space security with economic issues (Genta, 2014). The concept of New Space means the domination of space by smaller states and private companies. The secondary goal is research, the primary goal is profit. It is the more achievable, the lower the costs of energy sources necessary for space flight or the progress in the miniaturization of satellites as supporting objects becomes lower (Sauer, 2017: 83). Finally, preparations for a private-public partnership in the field of tourist flights are facilitated by the international agreements on co-financing the International Space Station ending in 2024.

The activity of non-state actors in space is deepening and the competition between commercial entities has clearly been increasing for several years. In the 90 s of the last century, there was a concentration of companies in the space sector. These are mainly American companies which, with the end of the era of American shuttle travel, created the United Space Alliance consortium, integrating Boeing and Lockheed Martin as main partners, proposing to NASA in 2011 to take over the Endeavor and Atlantis shuttles. However, it was not until 2012 that the technological emancipation of the private space sector became a breakthrough when Space X sent the Dragon C2 + spacecraft to the International Space Station, and when it became a party to two two-mission contracts with the US Department of Defense. On the other hand, British Virgin Galactic's pursuit of high specialization in space tourism paid off just five years after the first failed flight in November 2014, which seemed to hold back work on the development of space tourism. In February 2019, Virgin Galactic conducted a commercial flight with the participation of a Scottish cosmonaut, and in the fall of this year, after creating a holding with an American entity - Social Capital Hedosophia, it made its debut on the stock exchange. Last year was a period of 
acceleration in the activity of Asian companies interested in commercial activity in space, although the rocket tests of two Chinese companies: OneSpace and LandSpace were unsuccessful. In October 2019, another Chinese company i-Space announced that it had a commercial rocket and that it was ready for a commercial flight this year (Żywińska, 2019).

A unique phenomenon, endemic to space, is the business activity of celebrities and businessmen with names known from the cultural or digital technology sector (Rabij, 2015). In this case, we should talk about the activity of individuals in efforts to popularize the conquest of space. Microsoft co-founder Paul Allen, associated with Google: Larry Page and Eric Schmidt, are involved in tourism and space mining, and James Cameron, director of sf movies ("Terminator", "Alien" or "Avatar"), gives credibility to these sectors in the eyes of cinema lovers also as an investor. Jeff Bezos, founder of Amazon, whose revenues are estimated at \$131 billion, transfers over \$ 1 billion from a private account each year to the development of his space rocket company Blue Origin. Space Exploration Technologies (SpaceX) founder Elon Musk, recently in excess of $\$ 20$ billion, is the most influential innovator in space commercialization. Richard Branson, British billionaire founder of Virgin Galactic specializes in the concept of extraterrestrial tourism. The first flights are to be implemented in 2022. Yuri Milner, an Israeli-Russian entrepreneur, temporarily associated with M. Khodorkovsky (3.7 billion), announced three years ago a plan to reach the Alpha Centauri system (Rabij, 2015). At the same time, it is clearly visible how the contemporary policy of privatization of space activity collides with the beliefs of the traditionalist staff responsible for the security sector in the major space powers (Frankowski, 2017: 132). According to Frankowski, this results in a polyphony about the status of outer space, which distinguishes European countries from the USA. Private space companies with an established reputation undertake the service of military missions of countries that do not develop their own space sector on a satisfactory scale. Thus, there is a new space partnership, also postulated beyond the Atlantic.

\section{CONCLUSION}

Over the course of more than half a century, space policy has changed from purely defense and research to security and economic policy. Private companies that manufactured satellite or rocket components in the realities of the Cold War were under the control of specialized state space agencies. However, at the turn of the century, there was a partial emancipation of the private sector, which in Western countries took advantage of the slow process of limiting government spending on space purposes. NASA's slow withdrawal of funding for peaceful space exploration was influenced by the Challenger and Discovery shuttles disasters. As a result, combined with the clear emancipation of the private sector, interested in both bearing the risk of space exploration and monopolizing success, an increase in private investment in space exploration. As a result, it translated into the development of astrotourism and space tourism. With these comments in mind, it is possible, with high probability, to positively answer the question posed in the introduction to the research and analysis.

The implementation of the research goal allows for a positive verification of the research hypothesis. In the near future, private entities will set the direction of space tourism development. On the other hand, states will abandon their monopoly on regulatory and organizational powers in space exploration. However, for reasons of their own interests in the field of broadly understood sovereignty and security, they will leave control over this sector. It seems that the application of legislation regulating space activity of the private sector and adapting the current business models to space research and services may result not so much in the deep politicization of space as in its depoliticization. Currently, many countries interested in space activity have not introduced regulations regarding the economic and tourist use of space in their national legislation. Meanwhile, commercialization and privatization must stay within the limits of the existing legal architecture for space.

\section{REFERENCES}

Baiocchi, D., \& Welser, W.IV. (2015). The Democratization of Space: New Actors Need New Rules. Foreign Affairs, 94(3), 98-104.

Benghadbane, F., \& Khreis, S. (2019). The role of tourism marketing in enhancing tourism development: a comparative study between Constantine and Amman cities. GeoJournal of Tourism and Geosites, 24(1), 146-160. https://doi.org/10.30892/gtg.24112-349

Benzaghta, M.A., Elwalda, A., Mousa, M.M., Erkan, I., \& Rahman, M. (2021). SWOT analysis applications: An integrative literature review. Journal of Global Business Insights, 6(1), 55-73. https://doi.org/10.5038/2640-6489.6.1.1148

Bógdał-Brzezińska, A. (2020a). Cyberprzestrzeń i przestrzeń kosmiczna jako sfery bezpieczeństwa międzynarodowego - aspekty teoretyczne [Cyberspace and outer space as spheres of international security - theoretical aspects]. In Jurgilewicz, M. Delong, M., Michalski, K., Krzton, W., (eds.), Wyzwania bezpieczeństwa w XXI wieku, 129-142, Oficyna Wydawnicza Politechniki Rzeszowskiej, Rzeszów, (In Polish).

Bógdał-Brzezińska, A. (2020b). Mocarstwowość kosmiczna i cybernetyczna jako komponent zmian w obszarze bezpieczeństwa międzynarodowego [Space and cyber superpower as a component of changes in the area of international security]. In Bajor, P. (ed.), Bezpieczeństwo międzynarodowe. Aspekty metodologiczne i systemowe, 122-139, Wydawnictwo Uniwersytetu Jagiellońskiego, Kraków, Poland, (In Polish).

Bógdał-Brzezińska, A. (2020c). Information and Communication Technology (ICT) as a source of development of states and regions in the age of globalization. Journal of Geography, Politics and Society, 10(1), 15-22. https://doi.org/10.26881/jpgs.2020.1.03

Borowiec, A. (2017). Partnerstwo publiczno-prywatne: zagrożenia i bariery stosowania w polskich przedsiębiorstwach w świetle badań empirycznych [Public-private partnership: threats and barriers to application in Polish enterprises in the light of empirical research]. Zeszyty Naukowe Politechniki Poznańskiej. Organizacja i Zarządzanie, 75, 67-78, (In Polish). https://doi.org/10.21008/j.0239-9415.2017.075.05

Bryła, J. (2014). Delimitacja przestrzeni kosmicznej: cel, zasadność, rywalizacja interesów [Space delimitation: purpose, legitimacy, competition of interests]. Prace i Studia Geograficzne, 54, 7-27, (In Polish).

Buchan, R.J. (2016). Cyberspace, Non-State Actors and the Obligation to Prevent Transboundary Harm. Journal of Conflict \& Security Law, 21(3), 429-453.

Bütün, S., \& Önçel, S. (2019). Comparative content analysis of the websites of gastronomy cities rewarded by UNESCO creative cities network. GeoJournal of Tourism and Geosites, 26(3), 831-848. https://doi.org/10.30892/gtg.26313-401

Cater, C.I. (2010). Steps to Space; opportunities for astrotourism. Tourism Management, 31(6), 838-845. https://oi.org/10. 1016/j.tourman.2009.09.001

Chang, Y.W. (2017). A preliminary examination of the relationship between consumer attitude towards space travel and the development of innovative space tourism technology. Current Issues in Tourism, 20, 14, 1431-1453. https://doi.org/10.1080/13683500.2015.1005580

Chang, Y.W., \& Chern, J.S. (2016). Ups and downs of space tourism development in 60 years from moon register to spaceshiptwo CRASH. Acta Astronautica, 127(6), 533-541. https://doi.org/10.1016/j.actaastro.2016.06.008 
Chang, Y.W. (2015). The first decade of commercial space tourism. Acta Astronautica, 108, 79-91. https://doi.org/10.1016/j.actaastro.2014.12.004

Cohen, E. (2017). The paradoxes of space tourism, Tourism Recreation Research, 42:1, 22-31. https://doi.org/10.1080/02508281.2016.1239331

Colby, E. (2016). From Sanctuary To Battlefield: A Framework for a U.S. Defense and Deterrence Strategy for Space, Center for a New American Security, Washington, US.

Cole, S. (2015). Space tourism: prospects, positioning, and planning. Journal of Tourism Futures, 1(2), 131-140. https://doi.org/ 10.1108/JTF-12-2014-0014

Czajkowski, M. (2015). Przestrzeń kosmiczna a bezpieczeństwo międzynarodowe. Katalog problemów [Outer space and international security. The List of Issues]. In Gizicki, W. (ed.) Wybrane problemy bezpieczeństwa globalnego po zimnej wojnie, Instytut SądeckoLubelski, 99-115, Lublin, Poland, (In Polish).

Dolman, E.C. (2005). Astropolitik. Classical Geopolitics in the Space Age, Routledge, London-Portland, UK.

Fayos-Solá, E., Marín, C., \& Jafari, J. (2014). Astrotourism: No requiem for meaningful travel. Revista de Turismo y Patrimonio Cultural, 12, 663-671. https://doi.org/10.25145/j.pasos.2014.12.048

Fidler, D.P. (2008). A Theory of Open-Source Anarchy. Indiana Journal of Global Legal Studies, 15(1), $259-284$.

Frankowski, P. (2017). Outer Space and Private Companies: Consequences for Global Security. Politeja, 5(50), 131-147.

Gabriel, R.A., \& Koven, B.S. (2018). Malicious Non-state Actors and Contested Space Operations. Report to DHS S\&T Office of University Programs and DoD Strategic Multilayer Assessment Branch, College Park, US.

Genta, G. (2014). Private space exploration: A new way for starting a spacefaring society? Acta Astronautica, 104(2), 480-486. https://doi.org.10.1016/j.actaastro.2014.04.008

Gomes, J.R., Devezas, T.C., Belderrain, M.C., Vilela Salgado, M.C., \& de Melo, F.C.L. (2013). The Road to Privatization of Space Exploration: What Is Missing? 64 ${ }^{\text {th }}$ International Astronautical Congress, Institute for Aeronautics and Space, Beijing, China. Access 20. 02. 2021 https://www.researchgate.net/publication/289635460_The road to privatization_of_space_exploration_What_is_missing

Helms, M.M., \& Nixon, J.C. (2010). Exploring SWOT analysis - where are we now? Journal of Strategy and Management, 3, $215-251$. https://doi.org/10.1108/17554251011064837

Johnson, M.R., \& Daryl Martin (2016). The Anticipated Futures of Space Tourism. Mobilities, 11(1), 135-151. https://doi.org/10.1080/17450101.2015.1097034

Jones, K.L. (2018). Public-Private Partnerships: Stimulating Innovation in the Space Sector. Center for Space Policy and Strategy, El Segundo, USA.

King, A.K. (2020). The Future of Space Tourism. Congressional Research Service, R46500, https://crsreports.congress.gov. Access 28.07.2021.

Koshim, A.G., Sergeyeva, A.M., Saparov, K.T., \& Wendt J.A. (2019). Development of Scientific Tourism at Baikonur Cosmodrome Kazakhstan. GeoJournal of Tourism and Geosites, 24(1), 267-279. https://doi.org/10.30892/gtg.24121-358

Lenartowicz, A.J., \& Mosz, J. (2019). Stadiony i widowiska: Społeczne przestrzenie sportu [Stadiums and shows: Social spaces of sport]. WN Scholar, Warszawa, Poland, (In Polish).

Łoboda, J. (2015). Niektóre problemy rozwoju turystycznej przestrzeni kosmicznej [Some problems in the development of tourism space]. In Bilska-Wodecka, E. \& Sołjan, I. (eds.). Geografia na przestrzeni wieków. Tradycja $i$ wspótczesność. Profesorowi Antoniemu Jackowskiemu w 80. rocznicę urodzin, 287-297, Wydawnicwto IGiGP UJ, Kraków, Poland, (In Polish)

Oduntan, G. (2016). Aspects of the International Legal Regime concerning Privatization and Commercialization of Space Activities. Georgetown Journal of International Affairs, 17(1), 79-90.

Pásková, M., Budinská, N., \& Zelenka, J. (2021). Astrotourism-Exceeding Limits of the Earth and Tourism Definitions? Sustainability, 13, 373. https://doi.org/10.3390/su13010373

Peeters, P. (2018). Why space tourism will not be part of sustainable tourism. Tourism Recreation Research, 43(4), 540-543. https://doi.org/10.1080/02508281.2018.1511942

Rabij, M. (2015). Doktorant oligarchii [PhD student in the oligarchy]. Newsweek, 20.12.2015. Access 30.02.2021. (In Polish). https://www.newsweek.pl/biznes/jurij-milner-rosyjski-miliarder-poszuka-zycia-w-kosmosie/r9by504

Różycki, P., \& Kruczek, Z. (2017). Turystyka kosmiczna: historia i przyszłość oraz jej miejsce w typologii turystyki kulturowej [Space tourism: history and future and its place in the typology of cultural tourism]. In Owsianowska, S. \& Winiarski, R. (eds.) Antropologia turystyki, 173-189, Akademia Wychowania Fizycznego im. Bronisława Czecha w Krakowie, Kraków, Poland, (In Polish).

Sauer, F. (2017). From Cyberspace to Outer Space. International Politics in Seemingly Boundless Spaces. International Reports of the Konrad-Adenauer-Stiftung, 1, 79-89.

Smith, V.L. (2000). Space Tourism: The 21st Century "Frontier". Tourism Recreation Research, 25(3), 5-15. https://doi.org/10. $1080 / 02508281.2000 .11014920$

Soleimani, S., Bruwer, J., Gross, M.J., \& Lee, R. (2019). Astro-tourism conceptualisation as special-interest tourism (SIT) field: A phenomenological approach. Current Issues in Tourism, 22, 2299-2314. https://doi.org/10.1080/13683500.2018.1444021

Spector, S., Higham, J.E.S., \& Doering, A. (2017). Beyond the biosphere: tourism, outer space, and sustainability. Tourism Recreation Research, 42(3), 273-283. https://doi.org/10.1080/02508281.2017.1286062

Toivonen, A. (2020). Sustainability dimensions in space tourism: the case of Finland. Journal of Sustainable Tourism. https://doi.org/10. 1080/09669582.2020.1783276

Webber, D. (2013). Space tourism: Its history, future and importance. Acta Astronautica, 92, 2, 138-143. https://doi.org/10.1016/i.actaastro.2012.04.038

Weinzierl, M. (2018). Space, the Final Economic Frontier. Journal of Economic Perspectives, 32(2), 173-192. https://doi.org/10.1257/jep.32.2.173

Welser, W.IV. (2016). The Democratization of Space. Access 28.02.2021. https://www.rand.org/blog/2016/03/the-democratization-of-space.html

Wendt, J.A. \& Bógdał-Brzezińska, A. (2018). Problematyka, metody i problemy badań w geografii turystycznej [Problems, methods and problems of research in tourism geography]. In Olszewski-Strzyżowski, D.J., Dróżdż R. \& Pasek M., (eds.), Turystyka. Nowe Trendy, Zeszyty Naukowe, 7, 7-42, (In Polish).

Zhang, Y., \& Wang, L. (2020). Progress in space tourism studies: a systematic literature review. Tourism recreation research, 1-12. https://doi.org/10.1080/02508281.2020.1857522

Żywińska, J. (2019). Chiński konkurent SpaceX ma już podobną rakietę [The Chinese competitor, SpaceX, already has a similar rocket]. Rzeczpospolita, Access 24.02.2021, (In Polish). https://cyfrowa.rp.pl/technologie/38566-chinski-konkurent-spacex-ma-juz-podobna-rakiete

*** Anarchy in Space? (1958). The World Today, 14, 9 (Sep.), 390-398.

*** ASG Analysis: Reforms, Opportunities, and Challenges in India's Space Sector. (2020). Albright Stonebridge Group, 30 June 2020. Access 29.07.2021. https://www.albrightstonebridge. com/files/ASG\%20Analysis\%20\%20India\%27s\%20Space\% 20Sector.pdf

*** Policy and Strategy. (2018). Access 29.07.2021. https://aerospace.org/sites/default/files/2018-06/Partnerships_Rev_5-4-18.pdf,

*** Changes in the U.S. Commercial Space Industry [US-CSI] (2016). Access15.07.2021. https://crsreports.congress.gov/product/ pdf/IF/IF10415

*** The Pros and Cons of Privatizing Space Exploration. (2017). Forbes, 4.04.2017. Access 29.02.2021 https://www.forbes.com/ sites/quora/2017/04/04/the-pros-and-cons-of-privatizing-space-exploration/?sh=790844233319 